\title{
Stabilna angina pektoris
}

\author{
Jelena Stepanović, Miodrag Ostojić, Ana Đorđevic Dikić, Ivana Nedeljković, Vojislav Giga, \\ Branko Beleslin
}

Klinika za kardiologiju, Klinički centar Srbije; Medicinski fakultet, Univerzitet u Beogradu

S tabilna angina pektoris je klinički sindrom za koji je karakterističan bol u grudima (ili nelagodnost u grudima) prouzrokovan ishemijom miokarda, ali bez njegove nekroze, izazvan fizičkim naporom ili emocionalnim stresom. Bol prolazi posle nekoliko minuta odmora ili nitroglicerina datog sublingvalno. Anginozni bol najčešće označava aterosklerotsko oštećenje koronarnih arterija, ali se može javiti i kod bolesnika sa aortnom stenozom, hipertrofičnom kardiomiopatijom ili hipertenzijom (obično u 2 ili 3 . stadijumu) bez oštećenja koronarnih arterija. ${ }^{1}$

\section{Anamneza}

Pažljivo uzeta anamneza ostaje kamen temeljac za dijagnozu angine pektoris. Pri uzimanju anamnestičkih podataka o bolu u grudima najvažnije je razlučiti da li se radi o bolu kardijalnog ili nekardijalnog porekla. Detaljan opis bola podrazumeva 7 karakteristika: lokalizaciju, kvalitet, trajanje, učestalost, širenje, faktore koji ga provociraju i faktore koji dovode do njegovog prestanka. ${ }^{1}$
Bol u grudima može biti klinički klasifikovan u tri grupe ${ }^{2}$ :

1) Tipičan ili definitivno angina

a) substernalna nelagodnost u grudima sa karakterističnim kvalitetima i trajanjem,

b) provocira se naporom ili emocionalnim stresom, i c) smanjuje se u odmoru ili na nitroglicerin.

2) Atipičan ili verovatno angina - nelagodnost $u$ grudima sa 2 gore navedene tipične anginozne karakteristike.

3) Nekardijalni bol u grudima - nelagodnost u grudima sa 1 ili nijednom gore navedenom tipičnom anginoznom karakteristikom

Radi boljeg i preciznijeg ocenjivanja težine anginoznih tegoba na osnovu anamnestičkih podataka, Kanadsko kardiovaskularno udruženje (CCS - Canadian Cardiovascular Society) dalo je klasifikaciju angine pektoris koja je predstavljena u Tabeli $1 .^{3}$

Tabela 1. CCS klasifikacija angine pektoris

\begin{tabular}{|l|l||}
\hline Klasa & Nivo simptoma \\
\hline Klasa I & $\begin{array}{l}\text { Uobičajena fizička aktivnost ne dovodi do pojave angine. } \\
\text { Angina se javlja samo pri izrazitom ili brzom ili produženom fizičkom naporu. }\end{array}$ \\
\hline Klasa II & $\begin{array}{l}\text { Lako ograničenje uobičajene aktivnosti. } \\
\text { Angina se javlja prilikom hodanja ili brzog penjanja uz stepenice, hodanja uzbrdo ili usled } \\
\text { fizičkog napora nakon jela, na hladnoći, na vetru, usled emotivnog stresa, ili samo unutar prvih } \\
\text { nekoliko sati posle buđenja. }\end{array}$ \\
\hline Klasa III & $\begin{array}{l}\text { Značajno ograničena uobičajena fizička aktivnost } \\
\text { Angina se javlja prilikom hoda jedan ili dva bloka* na ravnom ili prilikom penjanja stepenicama } \\
\text { jedan sprat normalnim korakom pri normalnih uslovima. }\end{array}$ \\
\hline Klasa IV & Nemogućnost obavljanja bilo koje fizičke aktivnosti bez pojave simptoma. ili angina u miru" \\
\hline
\end{tabular}

* Ekvivalent 100-200m

Principi dijagnostike stabilne angine pektoris opisani su u posebnom tekstu Dijagnostika koronarne bolesti u ovom broju časopisa. Na Slici 1. je predstavljen samo algoritam za inicijalnu procenu pacijenata sa kliničkim simptomima stabilne angine pektoris.

\subsection{Ciljevi lečenja}

1) Poboljšanje prognoze prevencijom pojave infarkta i smrtnog ishoda

2) Smanjivanje ili nestanak simptoma

\subsection{Opšte preporuke i nefarmakološki postupci}

- Potrebno je informisati pacijenta i njegovu bližu rodbinu o prirodi angine pektoris, i značaju dijagnoze i preporučljivih vidova lečenja.

- Dati savet o postupanju pri pojavi akutnog anginoznog napada, npr. da miruje, o aktivnostima koje provociraju napad i upotrebi sublingvalnih nitrata za akutno popuštanje simptoma.

- Potrebno je informisati pacijenta o mogućim neželjenim efektima upotrbe nitrata i njihovoj adekvatnoj preventivnoj upotrebi. 


\section{Algoritam za početnu evaluaciju pacijenata sa kliničkim simptomom stabilne angine pectoris}

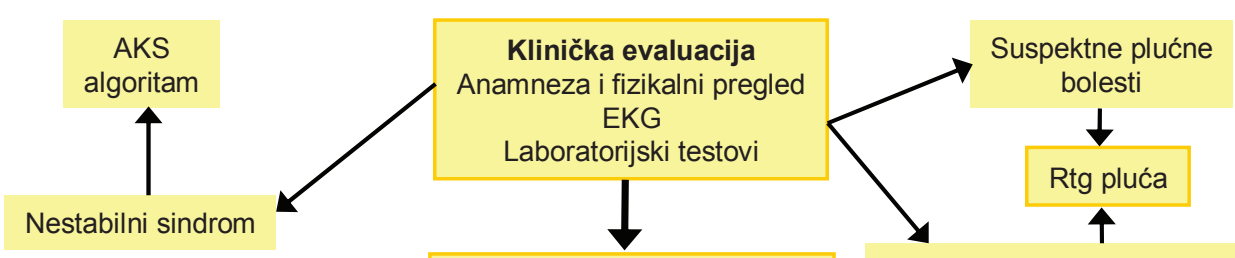

Procena ishemije Test fizičkim opterećenjem ili stres eho imaging

Ponovna procena Pozvati se na istraživanja i / ili diferencijalne dijagnoze

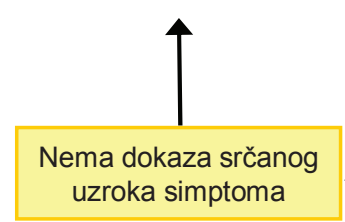

Ponovna procena verovatnoće ishemije kao uzroka simptoma
Ili farmakološki stres imaging

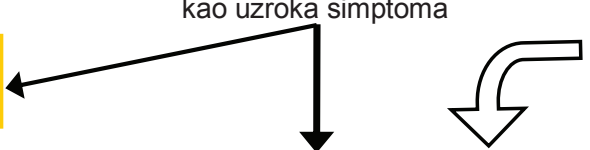

Evaluacija prognoze na bazi kliničke evaluacije i neinvazivnih testova

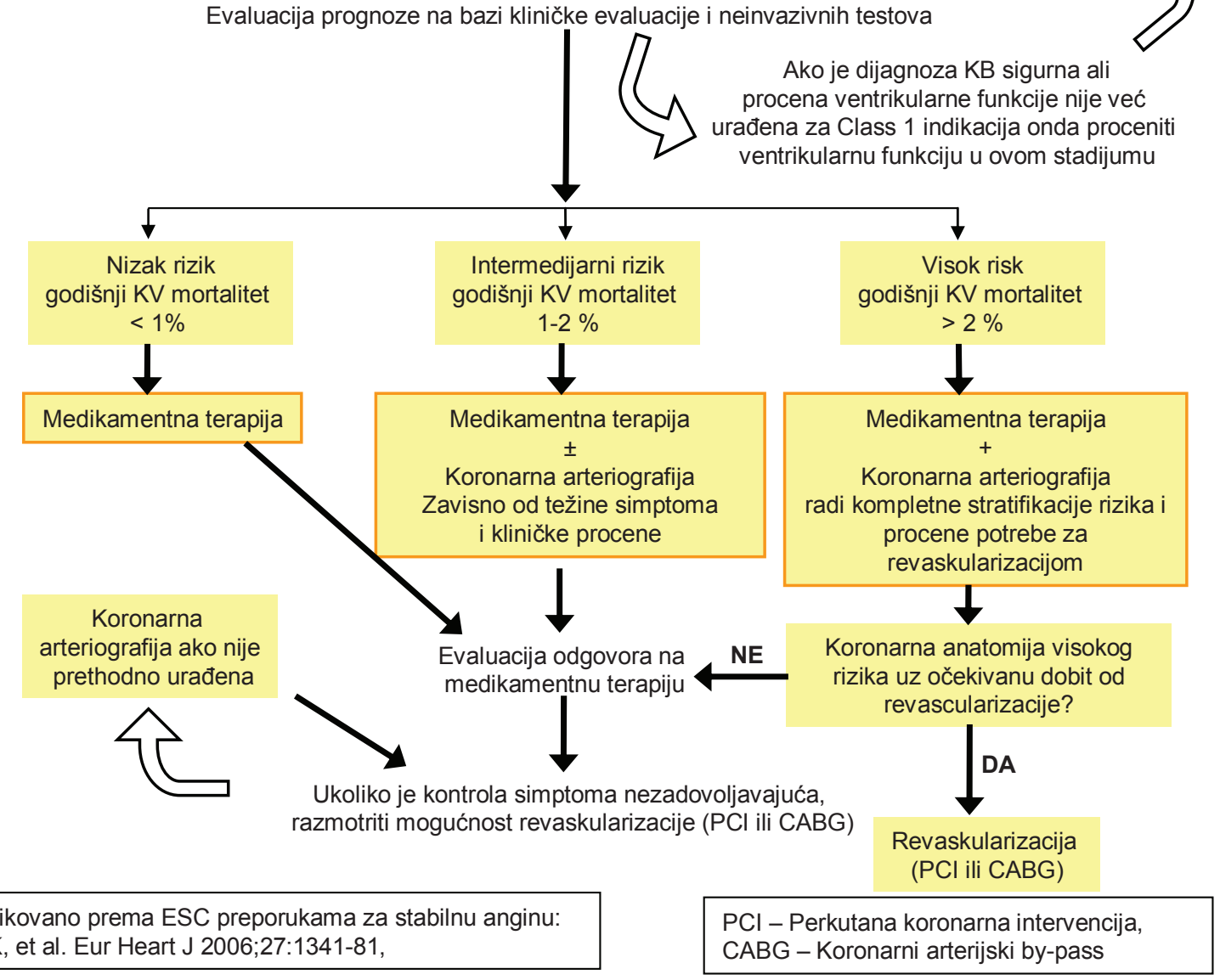

- Potrebno je informisati pacijenta da u slučaju trajanja simptoma $>10-20$ minuta nakon mirovanja i/ili ne popuštanja simptoma na sublingvalne nitrate, potraži medicinsku pomoć.

- Savetovati pacijenta da prestane pušiti cigarete.

- Predložiti pacijentu mediteransku dijetu, gde je u osnovi unos povrća, voća, ribe i piletine. Ukoliko je pacijent gojazan, potrebna je redukcija telesne težine.

- Umereni unos alkohola može biti koristan, ali je prekomerni unos štetan.

- Preporučuje se unos ribljeg ulja bogatog omega-3 masnim kiselinama ( $n-3$ polinezasićene kiseline) najmanje jednom nedeljno.

- Savetovati fizičku aktivnost u skladu sa zdravstenim stanjem pacijenta.

- Modifikovana „šifra“ Evropskog udruženja kardiologa za sekundarnu prevenciju glasi: 0-3-5-120-4-2-0, gde je razlika u odnosu na primarnu prevenciju na nešto nižim vrednostima krvnog pritiska, ukupnog i LDL holesterola. 
- Adekvatno lečenje pridruženih oboljenja, poput diabetesa i hipertenzije. Kod pacijenata sa udruženim diabetesom i/ili oboljenjem bubrega, održavati arterijski krvni pritisak $<130 / 80 \mathrm{mmHg}$. Lečenje više faktora (multifactor intervention) kod pacijenata sa diabetesom može značajno smanjiti kako kardiovaskularne tako i druge diabetske komplikacije.

- Potrebno je korigovati anemiju ili hipertireozu u slučaju njihove pojave.

- Seksualna aktivnost može dovoditi do anginoznih napada. Korisno je uzimanje nitroglicerina pre seksualne akivnosti. Osobe sa koronarnom bolešću mogu bezbedno koristiti inhibitore fosfodiesteraze (sildenafil, tadafil ili vardenafil), dok se ne preporučuje kod osoba na terapiji dugodelujućim nitratima.

\subsection{Farmakološko lečenje simptoma $i$ ishemije}

U zavisnosti od simptoma, funkcionalne i anatomske složenosti, stabilna angina pektoris se može lečiti medikamentnom terapijom i/ili revaskularizacijom.

Lekovi koji smanjuju potrebu miokarda za kiseonikom i/ili povećavaju protok krvi kroz ishemijske regione mogu dovesti do smanjenja simptoma angine pectoris i znakova ishemije (takođe $i$ „silent” ishemije). Najčešće korišćeni antianginozni lekovi su beta blokatori, kalcijumski antagonisti i organski nitrati (Tabela 2a, 2b); mogu se koristiti i lekovi koji otvaraju K-kanale. U skorije vreme su postali dostupni i inhibitori sinusnog čvora, a mogu se koristiti i metabolički agensi ${ }^{1}$.

Tabela 2a.

\begin{tabular}{|c|c|c|c|}
\hline \multicolumn{4}{|c|}{ Lekovi za smanjenje simptoma i ishemije } \\
\hline Lek & Dejstvo & Komentar & Preporuke \\
\hline $\begin{array}{l}\text { Kratko- } \\
\text { delujući nitati }\end{array}$ & \multirow{2}{*}{$\begin{array}{l}\text { Venodilatacija, } \\
\downarrow \text { dijastoInog punjenja, } \downarrow \\
\text { smanjen intrakardijani } \\
\text { pritisak, } \downarrow \text { subendokardna } \\
\text { perfuzija }\end{array}$} & $\begin{array}{l}\text {-Sublingvalna primena } \\
\text { - Profilaksa u određenim } \\
\text { situacijama }\end{array}$ & IC \\
\hline $\begin{array}{l}\text { Dugo-delujući } \\
\text { nitrati }\end{array}$ & & $\begin{array}{l}\text {-Oralne ili transdermalne } \\
\text { formulacije } \\
\text { - Potreba za periodom bez nitrata }\end{array}$ & IC \\
\hline Beta-blokatori & $\begin{array}{l}\downarrow \text { potreba za kiseonikom } \\
\text { usled } \downarrow \text { frekvence } \\
\downarrow \text { kontraktilnosti } \\
\downarrow \text { krvnog pritiska }\end{array}$ & $\begin{array}{l}\text {-manje neželjenih dejstava } \\
\text { korišcenjem B1-receptor } \\
\text { selektivnih lekova } \\
\text {-Doza se titrira prema simptomima } \\
\text { i frekvenci } \\
\text {-Dokazano smanjuje učestalost } \\
\text { simptoma i poboljšava toleranciju } \\
\text { fizičkog napora } \\
\text { - Može dovesti do pogoršanja } \\
\text { vazospastične angine }\end{array}$ & IA \\
\hline $\begin{array}{l}\text { Antagonisti } \\
\text { kalciumskih } \\
\text { kanala }\end{array}$ & $\begin{array}{l}\text { - Heterogena klasa } \\
\text { - Sistemska karonama } \\
\text { vazodilatacija usled inhibicije } \\
\text { ulaska kalcijuma kroz L-tip kanala } \\
\text {-Verapamil i dittiazem takođe } \\
\text { smanjuju kontraktilinost miokarda } \\
\text {-SF i AV sprovođenje } \\
\text { dihidropiridina koji su više }\end{array}$ & $\begin{array}{l}\text { - Dokazano smanjuju učestalost simptoma i } \\
\text { poboljšavaju toleranciju fizičkog napora } \\
\text { - Podjednako efikasni kao beta-blokatori } \\
\text { - Posebno efikasni kod vazospastične angine }\end{array}$ & IA \\
\hline $\begin{array}{l}\text { Lekovi koji } \\
\text { otvaraju } \\
\text { kalijumske kanale }\end{array}$ & 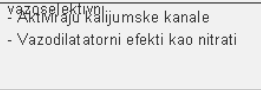 & $\begin{array}{l}\text { - Pokazano da nikorandil smanjuje učestalost } \\
\text { sminnog ishoda, IM hospitalizacija zbog } \\
\text { angine u jednoj velikoj RCT uz ostalu terapiju } \\
\text { - Nisu dostupni u svim zemljama }\end{array}$ & IC \\
\hline $\begin{array}{l}\text { Inhibitori sinusnog } \\
\text { čvora }\end{array}$ & $\begin{array}{l}\text { - Smanjuju srčanu frekvencu } \\
\text { direktnom inhibicijom If kanala u } \\
\text { sinusnom čvoru }\end{array}$ & $\begin{array}{l}\text { - Pokazano je da je ivabradin efik asan u } \\
\text { smanajejiu simptoma kaa i beta-blokator (u } \\
\text { jednjoj randomizovanoj kliničkoj studiji....ali } \\
\text { ima i SHIFT studija) }\end{array}$ & IIa B \\
\hline $\begin{array}{l}\text { Metabolǐki } \\
\text { agensi }\end{array}$ & $\begin{array}{l}\text {-Relativno povećavaju korišcénje } \\
\text { glukoze u odnosu na metabolizam } \\
\text { masnih kiselina }\end{array}$ & $\begin{array}{l}\text {-Ograničen hemodinamski efekat } \\
\text { - Trimetazidin nije dostupan u svim zemljama } \\
\text {-Ranolazin još nije registrovan u Evropi }\end{array}$ & $11 \mathrm{lb} B$ \\
\hline
\end{tabular}

\section{Tabela 2b.}

Algoritam za farmakološke lečenje stabilne angine pektoris

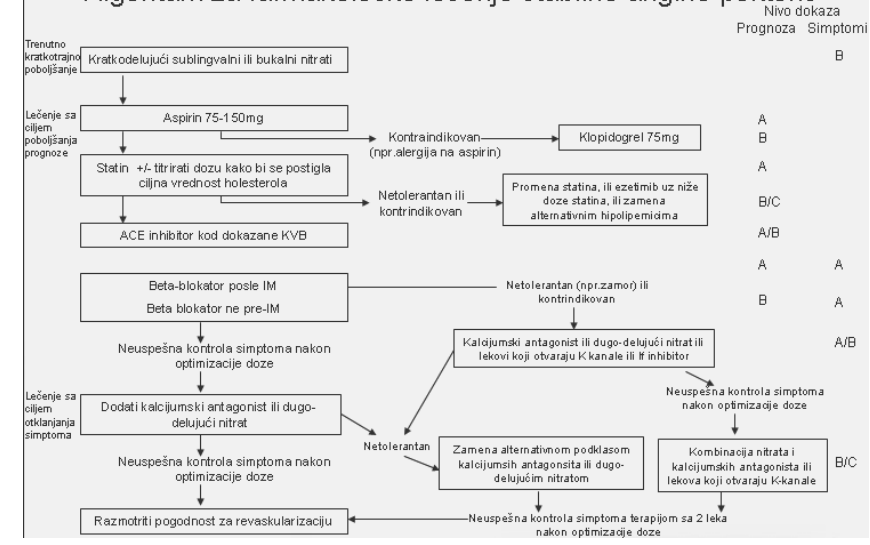

Ciljevi medikamentne terapije su otklanjanje ili smanjenje anginoznih tegoba i poboljšanje prognoze.

Navedeni algoritam pokazuje da lekovi koji modifikuju bolest prevenirajući infarkt miokarda i smrt su: aspirin, statini, ACE inhibitori/blokatori angiotenzinskih receptora, beta blokatori za bolesnike sa prebolelim infarktom miokarda i/ili disfunkcijom leve komore.

A lekovi koji smanjuju anginozne tegobe i redukuju ishemiju su: beta blokatori, kalcijumski antagosnisti i nitrati.

Ishemija miokarda javlja se usled disbalansa u snabdevanju miokarda kiseonikom i njegovim potrebama koje su definisane tzv. duplim proizvodom (srčana frekvenca x sistolni krvni pritisak). Iz tog razloga, svi antianginozni lekovi su usmereni na smanjenje potrošnje kiseonika od strane miokarda (smanjenjem srčane frekvence i/ili krvnog pritiska: beta-blokatori, nedihidropiridinski kalcijumski antagonisti, svi antihipertenzivi, vazodilatatori). Kod terapije vazospastične angine (Prinzmetal) bitni su i vazodilatatori (dugo i kratkodelujući nitrati i kalcijumski antagonisti).

Na progresiju koronarne ateroskleroze, koja je u stvari proces aterotromboze, a samim tim i na simptome, a što je još važnije, na prognozu, esencijalno deluju sledeće grupe lekova: statini, antiagregacioni lekovi (prevashodno aspirin), ACE inhibitori i beta-blokatori.

COURAGE studija ${ }^{4}$ je obuhvatila 2287 randomizovanih pacijenata sa poznatom značajnom koronarnom bolešću i dokazanom miokardnom ishemijom koji su bili samo na optimalnoj medikamentnoj terapiji (OMT) ili $\mathrm{OMT}+\mathrm{PCl}$. Nakon 4.6 godina praćenja (medijana vremena praćenja), nije bilo značajne razlike među grupama OMT i OMT+PCl za kumulativnu smrtnost i nefatalni infarkt miokarda (18.5\% vs. $19.0 \%$, HR 1.05, Cl 0.87-1.27; $\mathrm{p}=0.62)$; $\mathrm{MI}(2.5 \%$ vs. $13.2 \%, \mathrm{HR} 1.13, \mathrm{Cl} 0.87-1.43$; $\mathrm{p}=0.33$ ), moždni udar ( $20 \%$ vs. $19.5 \%, \mathrm{HR} 1.05, \mathrm{Cl} 0.87-$ 1.27; $p=0.62$ ) ili hospitalizaciji usled pojave nestabilne angine ( $11.8 \%$ vs. $12.4 \%$, HR 1.07, Cl 0.84-1.37; $p=0.56)$

Autori ove studije ${ }^{4}$ su zaključili da kod pacijenata sa stabilnom anginom pektoris inicijalna PCl terapija ne smanjuje rizik od smrtnog ishoda, infarkta miokarda ili teških kardiovaskularnih događaja kada se pridoda optimalnom medikamentnom lečenju. 


\subsection{Uticaj postojanja ishemije na prognozu}

Tokom proteklih 20 godina uočen je negativni uticaj dokazane ishemije na klinički ishod (smtni ishod, infarkt miokarda, AKS, pojava angine). Kod simptomatskih pacijenata bez dokazane ishemije miokarda ili sa vrlo malo dokaza koji govore u prilog ishemije, ne postoji prognostička korist od revaskularizacije, dok kod asimptomatskih pacijenata sa značajnom ishemijom miokarda ta korist postoji.

U maloj nuklearnoj sub-studiji COURAGE studije (u kojoj nije pokazano bolje ukupno preživljavanje pacijenata lečenih $\mathrm{PCl}$ u odnosu na medikamentno lečenje) koja je obuhvatila nešto više od 300 pacijenata, 100 pacijenata sa $>10 \%$ ishemijskog miokarda je imalo manji rizik od smrtog ishoda ili infarkta miokarda koji su imalii revaskularizaciju. $^{5}$

\subsection{Revaskularizacija miokarda kod stabilne angine} pektoris

Glavne indikacije za revaskularizaciju kod stabilne angine pektoris su održavanje simptoma uprkos medikamentnom lečenju i/ili sa ciljem poboljšanja prognoze.

Indikacije za primenu ne samo OMT već i revaskularizacije (CABG ili $\mathrm{PCI}$ ) date su u Tabeli 3.

U Tabeli 3. i 4. prikazane su preporuke o načinu revaskularizacije kod bolesnika sa različitom anatomskom kompleksnošću koronarne bolesti. Generalno uzevši, što je anatomija koronarne bolesti kompleksnija (izraženo putem SYNTAX skora), to hirurška revaskularizacija miokarda ima više prednosti u odnosu na PCl.

Tabela 3. Indikacije za revaskularizaciju kod stabilne angine pektoris ili „silent “ ishemije”

\begin{tabular}{|c|c|c|c|}
\hline & Anatomski nalaz IBS & Klasa & Nivo \\
\hline \multirow[t]{6}{*}{ Prema prognozi } & Stenoza glavnog stabla (LM) $>50 \% *$ & 1 & $A$ \\
\hline & Svaka proksimalna stenoza LAD > 50\% & 1 & $\Delta$ \\
\hline & 2 KS ili 3KS uz oštetećenu funkciju LK* & 1 & B \\
\hline & Dokazano veliko područje ishemije (>10\% LK) & 1 & B \\
\hline & Pojedinačna stenoza krvnog suda koja ostaje $>50 \% *$ & 1 & C \\
\hline & $1 \mathrm{KS}$ bez stenoze proksimalne LAD i bez ishemije LK >10\% & III & A \\
\hline \multirow[t]{3}{*}{$\begin{array}{l}\text { Prema } \\
\text { simptomima }\end{array}$} & $\begin{array}{l}\text { Svaka stenoza }>50 \% \text { sa simptomima angine ili ekvivalentom angine, } \\
\text { koja ne reagije na OMT }\end{array}$ & 1 & \\
\hline & $\begin{array}{l}\text { Dispneja / HSI i ishemija LK>10\% / vijabilnost u zoni koja je } \\
\text { vaskularizovana suženom koronarnom arterijom >50\% }\end{array}$ & Ila & B \\
\hline & Nema simptoma sa OMT & III & C \\
\hline
\end{tabular}

*sa dokumentovanom ishemijom ili FFR<0,80 za angiografski dijametar stenoze $50-90 \%$

KS, krvni sud; LK, leva komora; HSI hronična srčana insuficijencija

Tabela 4. Indikacije za CABG vs. PCI kod stabilnih pacijenata sa promenama podesnim za obe procedure i niskim rizikom hirurškog mortaliteta7

\begin{tabular}{|l|l|l|}
\hline Anatomski nalaz IBS & Favorizuje CABG & Favorizuje PCI \\
\hline 1 KS ili 2 KS - bez proksimalne stenoze LAD & Ilb C & I C \\
\hline 1 KS ili 2 KS - proksimalna LAD & I A & Ila B \\
\hline $\begin{array}{l}3 \text { KS jednostavne lezije, potpuna funkcionalna revaskularizacija koja } \\
\text { se postiže sa PCI, SINTAX score } \leq 22\end{array}$ & I A & Ila B \\
\hline $\begin{array}{l}3 \text { KS kompleksne lezije, nepotpuna revaskularizacija koja se postiže } \\
\text { sa PCl, SINTAX score }>22\end{array}$ & I A & III A \\
\hline LM (izolovan ili 1 KS ostijum/proximalni segment) & I A & Ila B \\
\hline LM (izolovan ili 1 KS distalna bifurkacija) & I A & Ilb B \\
\hline LM + 2 KS ili $3 \mathrm{KS}$, SINTAX skor $\leq 32$ & I A & Ilb B \\
\hline LM + 2 KS ili 3 KS, SINTAX skor $\geq 33$ & I A & III B \\
\hline
\end{tabular}

Meta-analiza sedam randomizovanih kliničkih studija je jasno pokazala superiornost CABG-a u odnosu na medikamentnu terapiju kod lečenja određenih podgrupa koronarnih bolesnika, što i dalje predstavlja osnovu savremene CABG terapije. Kod bolesnika sa bolešću glavnog stabla i trosudovnom koronarnom bolešću pokazano je bolje preživljavanje nakon CABG, posebno ako je zahvaćen proksimalni segment LAD arterije. Korist je bila veća kod bolesnika sa težim simptomima, pozitiv- nim testom opterećenja pri malom stepenu opterećenja i smanjenom funkcijom leve komore ${ }^{8}$.

Revaskularizacija lezija bez funkcionalnog značaja, tj. bez testom provocirane miokardne ishemije nije indikovana. Druga indikacija za neinvazivno vizualizaciono ispitivanje pre revaskularizacije je otkrivanje vitalnog miokarda kod bolesnika sa lošom funkcijom leve komore. Bolesnici sa vitalnim ali disfunkcionalnim miokardom imaju veći rizik ako se ne revaskularizuju, dok bolesnici 
bez vitalnog miokarda nemaju poboljšanje nakon revaskularizacije. $^{7}$

Praktični aspekti o lečenju ovih bolesnika uključuju njihovo potpuno informisanje o koristi i riziku od svake metode lečenja. Npr, iako bolesnik ima klasičnu indikaciju za izvođenje CABG, potrebno je to prilagoditi pojedinim kliničkim stanjima, poput starosnog doba ili značajnih pridruženih komorbiditeta. Tabele 3 i 4 bi trebalo da čine osnovu preporuke od strane multidisciplinarnog srčanog tima (eng. heart team) prilikom informisanja bolesnika i dobijanja informisanog pristanka za izvođenje određene procedure. ${ }^{7}$

\section{Literatura}

1. Fox K., Garcia MA, Ardissino D., et al. Guidelines on the management of stable angina pectoris: executive summary: The Task Force on the Management of Stable Angina Pectoris of the European Society of Cardiology. Eur Heart J 2006;27(11):1341-81.

2. Diamond AG. A clinically relevant classifcitaion of chest discomfort. J Am Coll Cardiol 1983;1:574-5.
3. Campeau L. Grading of angina. Circulation 1976;54:522-3.

4. Boden WE, O'Rourke RA, Teo KK, et al. Optimal medical therapy with or without PCI for stable coronary disease. N Engl J Med 2007;356: 1503-1516.

5. Shaw LJ., Berman DS, Maron DJ, et al. Optimal medical therapy with or without percutaneous coronary intervention to reduce ischemic burden: results from the Clinical Outcomes Utilizing Revascularization and Aggressive Drug Evaluation (COURAGE) trial nuclear substudy. Circulation 2008;117:1283-1291.

6. Graham I., et al. European guidelines on cardiovascular disease prevention in clinical practice: full text. Fourth Joint Task Force of the European Society of Cardiology and other societies on cardiovascular disease prevention in clinical practice (constituted by representatives of nine societies and by invited experts). Eur J Cardiovasc Prev Rehabil 2007; 14 (Suppl 2):S1-113.

7. Wijns W., Kolh P., Danchin N., et al. Guidelines on myocardial revascularization: The Task Force on Myocardial Revascularization of the European Society of Cardiology (ESC) and the European Association for Cardio-Thoracic Surgery (EACTS). Eur Heart J 2010;31(20):2501-55.

8. Yusuf S., Zucker D., Peduzzi P., et al. Effect of coronary artery bypass graft surgery on survival:overview of 10 -year results from randomised trials by the Coronary Artery, Bypass Graft Surgery Trialists Collaboration. Lancet 1994;344:563-570. 